\title{
Some Achievement on Mountain Glacier Researches in China*
}

\author{
Shi Yafeng**
}

In Central Asia, mainly in west China, there is a series of well known high mountains and plateau partially covered by perennianl snow and glaciers. (Fig. 1) The melt-water from the glaciers nourishes many large rivers in Asia, such as the Indus, the Ganges, the $\mathrm{Nu}$ Jiang (Salween), the Lancang Jiang (Mekong), the Chang Jiang (Yangtze), the Huang He (Yollow River) etc. and offers essential conditions conducive to the development of agriculture under irrigation in the extensive arid inland basins of Central Asia. However, glacial activities may sometimes also give rise to catastrophic floods and debris flow. Since the year 1958, a specialized glacier investigation group with the name of the Alpine Ice and Snow Utilization Team was organized by Academia Sinica (Chinese Academy of Sciences), and latter it became the Lanzhou Institute of Glaciology and Cryopedology, for carrying out continuous expeditions in Qilian Shan, Tian Shan, Himalaya and Qinghai-Xizang (Tibet) plateau. In recent years this institute has also conducted research in the Karakorams inside Pakistan. Here I would like to introduce briefly to our Japanese colleagues some achievements of the Chinese scientists on mountain glacier researches in Central Asia, and at the same time to learn from you the advanced idea and experience of snow and ice studies in Japan.

I. The Distribution of Mountain Glacier in West China

At the beginning of sixties, we have published the

* Read at the Symposium of Present Asian Glaciers, sponsored by the Japanese Society of Snow and Ice. 11 October 1979, Nagoya.

** 施雅風 (蘭州水河凍土研究所): Lanzhou Institute of Glaciology and Cryopedology, Academia Sinica, Lanzhou, China primary figure of total area of glaciers in China at $44,000 \mathrm{~km}^{2}$ and the statistics in Qilian Shan and Tian Shan (Shi and Xie, 1964). Due to insufficiency of data, these figures were evidently under estimated. Recently, with the help of newly compiled aerial maps (1:50,000 and $1: 100,000)$ and satellite images $(1: 1,000,000)$ and the work of glacier inventory we are able to know the distribution of mountain glaciers in China in a more accurate and perfect way. Table 1 shows the general distribution of mountain glaciers in West China.

The total area of glaciers in China may be nearly one half of that in central Asia. The detailed work of glacier inventory has conducted the glacierized area of Qilian Shan from $2063 \mathrm{sq}$. km merely on the base of maps (Shi et al., 1980) decreasing to $1972 \mathrm{sq} . \mathrm{km}$ by proof reading and correction from air photos (Wang Zbungtai, unpublished work 1980).

From Fig. 1. we can see clearly that the mountain $\mathrm{g}$ aciers and snowline in West China have a higher position as compared with other regions in the same latitude, and make irregular concentric circles of isochions. The snowline of some glaciers in the southern and western part of Qinghai-Xizang plateau reaches as high as $6,000-6,200 \mathrm{~m}$ which is the highest in Northern Hemisphere. This phenomenon may be owing to: (1) West China is lying in the interior of Eurasia far from the sea, the degree of its continentality is higher, and the precipitation decreases unevenly and abruptly from the marginal mountains of Central Asia to the inner plateau. Isochions elevate following the decrease in precipitation. In the southeastern part of Xizang Autonomous Region which is the main thoroughfare for the strong monsoon from the Indian 


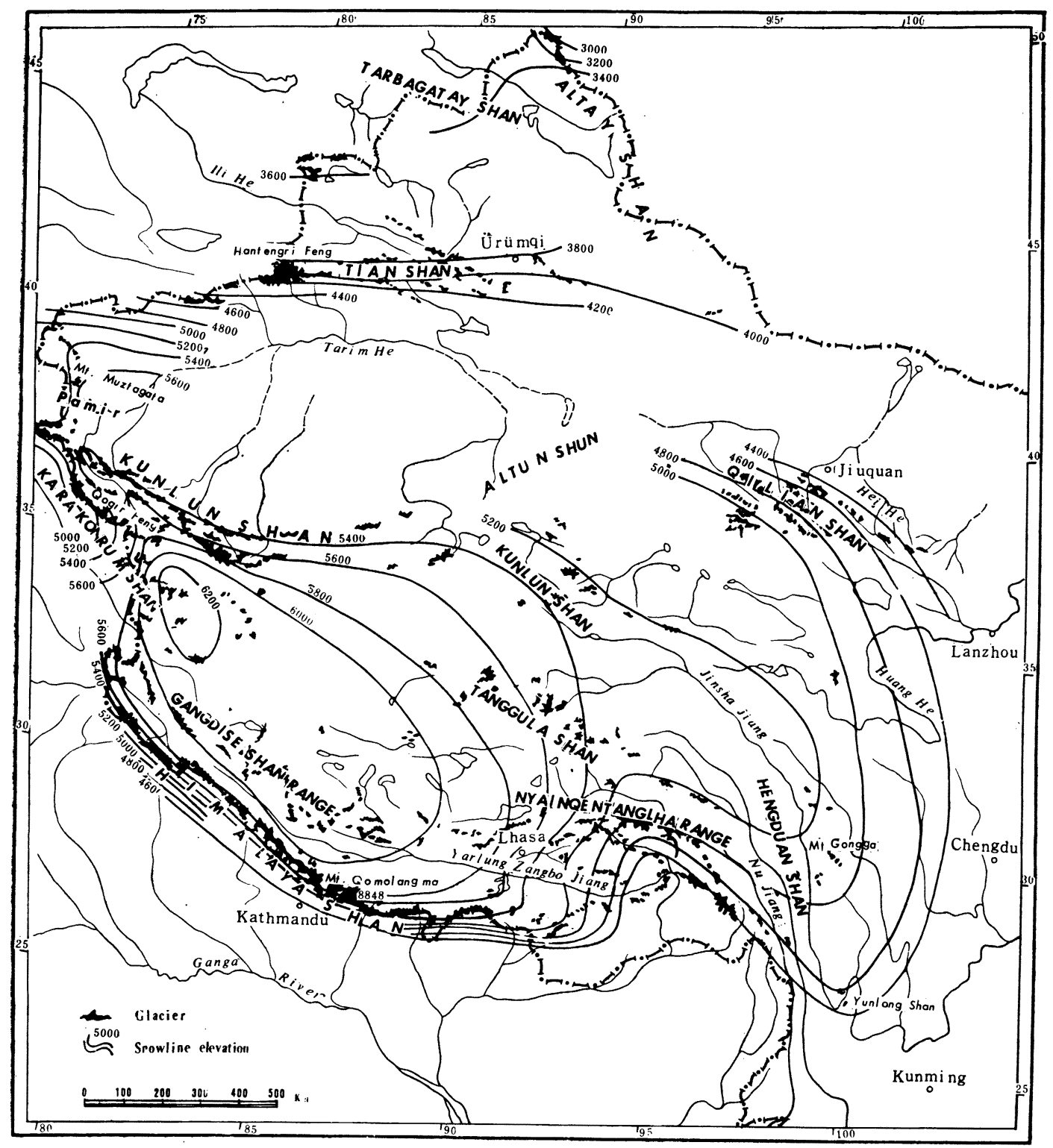

Fig. 1 Distribution of existing glaciers and snowline elevations in China

Ocean to enter the plateau, abundant precipitation makes the snowline descending to about $4,500 \mathrm{~m}$ a.s.l. It is about $1,500 \mathrm{~m}$ lower than that of the northern slope of middle Himalaya and western Xizang. The fact that the snowline on the southern slope of Himalaya is lower than that on the northern is also dependent on difference of precipitation. (2) The absorption of solar radiation on the vast extent of Qinghai-Xizang plateau is greater than its surrounding low-lands. It becomes a great perennial heat source sending thermal flux constantly to the atmosphere. The global solar radiation and the effective radiation in the central-western part of plateau have the highest values in China, thus also elevate the height of snowline.

The main districts of glaciers in China occur in the following regions:

1. Khantengri-Harlektau Shan in the Middle Part 
Table 1 Glacierized Area in China

\begin{tabular}{lccll}
\hline \multicolumn{1}{c}{ Mountains } & $\begin{array}{c}\text { Height of snowline } \\
(\mathrm{m})\end{array}$ & $\begin{array}{c}\text { Area of glaciers } \\
\left(\mathrm{km}^{2}\right)\end{array}$ & Sources & Investigator \\
\hline Altay Shan & $3,000-3,200$ & 287 & $1: 100,000$ map & Ren Binghui \\
Tian Shan & $3,600-4,400$ & 9,548 & $1: 100,000$ map & Ren Binghui et al. \\
Qilian Shan & $4,300-5,240$ & 1,969 & Glacier inventory & Wang Zhungtai et al. \\
Kunlun Shan & $4,700-5,800$ & 11,639 & Airphoto maps & Deng Yangxin et al. \\
Pamir & $5,500-5,700$ & 2,258 & Landsat images & Mi Desheng \\
Karakoram & $5,100-5,400$ & 3,265 & Landsat images & Mi Desheng \\
Qingtan Plateau & $5,600-6,000$ & 3,188 & Airphoto maps & Li Binyuan et al. \\
Tanggula & $5,400-5,700$ & 2,082 & Airphoto maps & Zhang Linyuan \\
Gangdise & $5,800-6,000$ & 2,188 & Landsat images & Jiao Keqin \\
Nyainqentanglha & $4,200-5,700$ & 7,536 & Airphoto maps & Li Jijun et al. \\
Hengduan Shan & $4,600-5,500$ & 1,456 & Airphoto maps & Li Jijun \\
Himalaya & $4,300-6,200$ & 11,055 & Landsat images & Mi Desheng \\
Total & & 56,471 & & \\
\hline
\end{tabular}

\section{of Tian Shan:}

This is the place where the highest peak of Tian Shan (Tomur peak-7,435 m) is situated. The area of glaciers in Chinese territory amounts to $4,900 \mathrm{~km}^{2}$. In the deep and broad glacial troughs, develops a kind of grand glaciers having main nourishment from avalanches, with ice tongues covered by supraglacial debris, well developed thermokarst phenomena, and with terminus gone down to about $3,000 \mathrm{~m}$ a.s.l. The largest is the South Inylchek Glacier $60.8 \mathrm{~km}$ long with an area of $544 \mathrm{~km}^{2}$. Its upper reach is in the territory of China, while its lower is in USSR, other large glaciers are: Tomur Su Glacier $(37.2 \mathrm{~km}$ long, area $\left.293 \mathrm{~km}^{2}\right)$, Tugebiliqi Glacier $(37.8 \mathrm{~km}$ long, area $\left.362 \mathrm{~km}^{2}\right)$ and Kalageyule Glacier $(32.0 \mathrm{~km}$ long, area $191 \mathrm{~km}^{2}$ ). Their meltwater nourishes the longest inland river-Tarim $\mathrm{He}$ in China.

2. West Kunlun Shan, East Pamir and North Karakoram Shan:

In this district of complicated mountain knot lies most of the glaciers in China. From $83^{\circ} \mathrm{E}$ to the places where China meets its boundary with the USSR, Afghanistan and Pakistan, the area of glaciers reaches $13,000 \mathrm{~km}^{2}$. Mt. Qogir $\left(\mathrm{K}_{2}\right)$ the second highest peak of the world towers on the Sino-Pakistan border, and several peaks over $7,000 \mathrm{~m}$ height are in this district. Although the precipitation over the snowline is still a puzzle, the whole landscape of the region is arid. The reason for the existence of so many glaciers may be mainly due to the strong uplifting of mountains in large area above the snowline. The Yinsukaiti Glacier in the northwest of Mt. Qogir $\left(\mathrm{K}_{2}\right)$ with a length of $41.5 \mathrm{~km}$, an area of $329 \mathrm{~km}^{2}$ and a terminus at $4,000 \mathrm{~m}$ a.s.l. is the longest glacier known in China (Zhang, 1980b). The second large glacier of this district is at the source of Yulongkax $\mathrm{He}$ in West Kunlun with $30.4 \mathrm{~km}$ long, an area of $131.3 \mathrm{~km}^{2}$ and a terminus at 5,120 $\mathrm{m}$ a.s.l. The meltwater from the glaciers in West Kunlun, East Pamir and North Karakoram irrigates jointly the famous oases of Kaxgar and Hotan on the southwestern fringe of Tarim Basin.

3. Eastern Nyainqentanglha and Himalaya Mountain District:

In this district the highest peak reaches $7,755 \mathrm{~m}$ a.s.l. (Nancha Barwa). Several other high peaks are about $6,000 \mathrm{~m}$ in combination with many deep valleys at two or three thousand metres a.s.l. The strong Indian monsoon gives favorable conditions for development of glaciers amounting an area of about $8,000 \mathrm{~km}^{2}$. The biggest of them is the Kaqing Glacier at $33 \mathrm{~km}$ long with an area of $172 \mathrm{~km}^{2}$ and a terminus gone down to $2,530 \mathrm{~m}$. The whole part of meltwater in this district all empties to Yarlung Zangbo Jiang (the upper portion of the Brahmaputra). Table 2 shows a comparison of the largest glaciers of the various mountain systems in China.

\section{Physical Characteristics and Classification of Mountain Glaciers in Central Asia}

Referring to the classification of glaciers by G. A. Avsiuk (1956) and P. A. Shumskii (1955), we have 
Table 2 A comparison of the largest valley glaciers of the various mountain ranges in China

\begin{tabular}{llccccc}
\hline Mountain Range & Name of glaciers & $\begin{array}{c}\text { Length } \\
(\mathrm{km})\end{array}$ & $\begin{array}{c}\text { Area } \\
(\mathrm{km})\end{array}$ & $\begin{array}{c}\text { Height of } \\
\text { peak } \\
(\mathrm{m})\end{array}$ & $\begin{array}{c}\text { Height of } \\
\text { snowline } \\
(\mathrm{m})\end{array}$ & $\begin{array}{c}\text { Height of } \\
\text { terminus } \\
(\mathrm{m})\end{array}$ \\
\hline Altay Shan & Halasi & 10.8 & 31.9 & 4,374 & $3,000-3,200$ & 2,410 \\
Tian Shan & Tugebiliqi & 37.8 & 361.7 & 6,934 & 4,050 & 2,752 \\
Qilian Shan & Laohugou & 10.0 & 21.5 & 5,481 & 4.770 & 4,265 \\
Pamir & Klayailak & 23.0 & & 7,719 & $5,500-5,700$ & 3,100 \\
Kunlun Shan & Yulung & 30.4 & 131.3 & 6,778 & 6,020 & 5,120 \\
Karakorum & Insukaiti & 41.5 & 329.2 & 7,295 & $4,800-5,200$ & 4,000 \\
Himalaya & Rongbuk & 22.2 & 86.9 & 8,846 & 5,800 & 5,754 \\
Nyainqentanglha & Kaqing & 35.0 & 172.0 & 6,356 & 4,510 & 2,530 \\
Tanggula Shan & Geladadong & 12.8 & 35.0 & 6.543 & 5.820 & 5,395 \\
Hengduan Shan & Heluqou & 14.5 & 25.6 & 7,556 & 4,600 & 2,850 \\
\hline
\end{tabular}

been classifying the mountain glaciers in West China into two types: the continental type and the maritime type. A majority of them in Altay, Tian Shan, Qilian Shan, Kunlun Shan, northern slope of Himalaya and inner mountains of Qinghai-Xizang plateau belongs to the former, while those in the mountains of southeastern part of Xizang Autonomous Region belong to the latter. According to the recent investigation, several large valley glaciers crossing several climatic zone in the Alpine mountains and having comparatively complex features need to be classified supplementarily as a complex type.

The parameters we have selected for the glaciers of continental type are: annual precipitation of accumulation area is relatively small, generally at $300-1,000$ $\mathrm{mm}$, with an annual air temperature at $-6^{\circ}--15^{\circ} \mathrm{C}$, the ice temperature at the lower part of the active layer in the tongue is generally below $-2{ }^{\circ} \mathrm{C}$ and its lowest occurring in the Laohugou Glacier of Qilian Shan reaches $-12.8^{\circ} \mathrm{C}$. Fig. 2 shows the ice temperature of a typical continental type glacier. Terminus of glaciers are generally restricted within the permafrost zone. According to the study of Xie Zichu, the transformation of snow into ice is mainly due to the action of infiltration and congelation. Fig. 3 shows three zones of ice formation in Laohugou Glacier. Between the equilibrium line and the firn line, there is a superimposed ice zone where ice formation is completed in 1-2 years. Above the firn line of glacfers, there is a comparatively large extent of infiltration zone or firn ice zone where the meltwater in the firn layer congelates and forms ice flakes. Over that is the cold infiltration and recrystallization zone, where the percolation of meltwater is so weak that a part of the firn forms ice through recrystallization. In Mt. Qomolangma area where the latitude is lower and the altitude is higher, the solar radiation is very strong and the melting phenomenon exists even above the height of $8,000 \mathrm{~m}$. On the East Rongbuk Glacier in the firn layer at the height of $7,450 \mathrm{~m}$ is found the whitecolored ice flake formed by the action of infiltration and congelation (Fig. 4). The firn collected from the summit of Xixabangma Feng at $8,012 \mathrm{~m}$ a.s.l. is also through the process of melting and recongelation. Here the difference in height of the infiltration-congelation zone reaches $3,000 \mathrm{~m}$ and may be the greatest in the world (Fig. 4).

The ablation of continental glaciers is considerably weaker, and the depth of annual ablation is only 0.6$1.0 \mathrm{~m}$ water layer. Even at the glacial terminus, the annual ablation on the bare ice rarely exceeds $3.5 \mathrm{~m}$. Among the heat sources of ablation, the solar radiation heat occupies $70-90 \%$ and the considerable part of heat exhausting by evaporation or sublimation (10-30 $\%$ ) under the condition of arid and cold climate which prominently reduces the intensity of ablation. On the ice tongues of the valley glaciers in the Himalaya develops a wonderful and splendid scenery of ice pyramids. This is mainly due to differential ablation by strong solar radiation at high angle acting on the irregular and moving ice surface at certain distance below the snowline. The time necessary for the formation, development and extinction of ice pyramids may last several decades even over one hundred years 


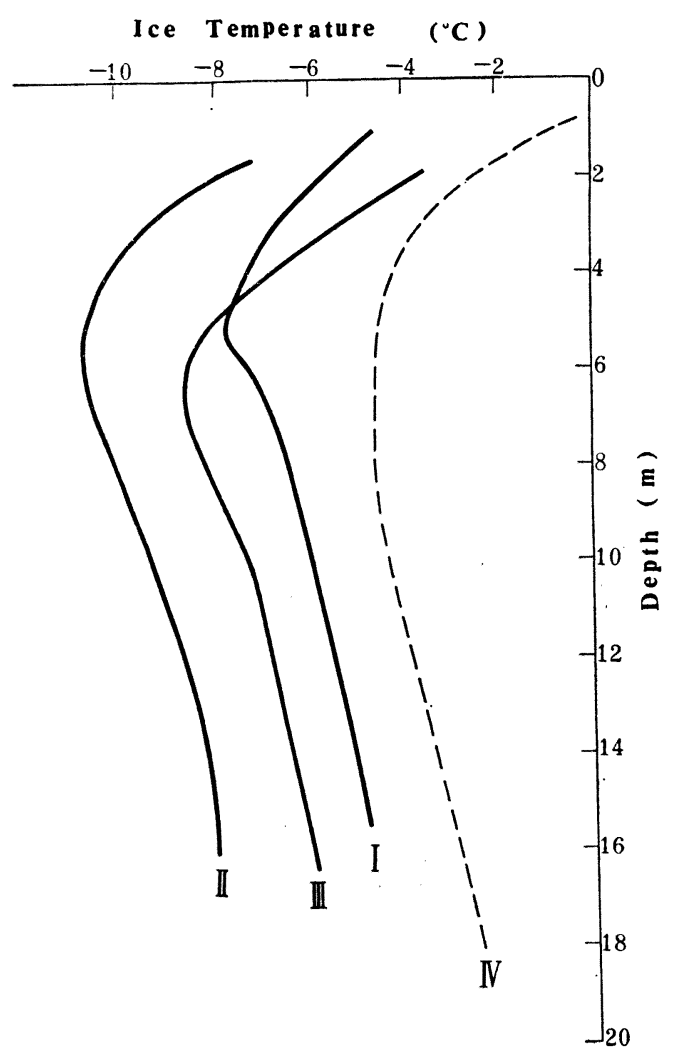

Fig. 2 The temperature of ice layer on No. 5 Glacier Yanglong $\mathrm{He}$, Qilian Shan at different elevations and comparison with Tilan Glacier of Tian Shan

I: At an elevation of 4,835 $\mathrm{m}$ (infiltration zone) on No. 5 Glacier of Yanglong He, Qilian Shan (29 June, 1977).

II: At an elevation of $4,648 \mathrm{~m}$ (near snowline) No. 5 Glacier of Yanglong He, Qilian Shan (29 June, 1977).

III: At an elevation of 4,513 $\mathrm{m}$ (ablation zone) on No. 5 Glacier of Yanglong $\mathrm{He}$, Qilian Shan (29 June, 1977).

IV: At an elevation of $4,300 \mathrm{~m}$ (ablation zone) on Tailan Glacier, Tian Shan (30 June, 1978).

(I, II, III from Huang Maohuan, IV from Wang Lilun, unpublished work, 1979)

(Shi et al., 1975). The scale of continental type glacier is comparatively small, their surface is generally clean, and a few of larger glaciers are covered with surface moraines. Their ablation is mainly superficial, and the under-ice channels are not well developed.

Although the basal sliding may occur at the sole of

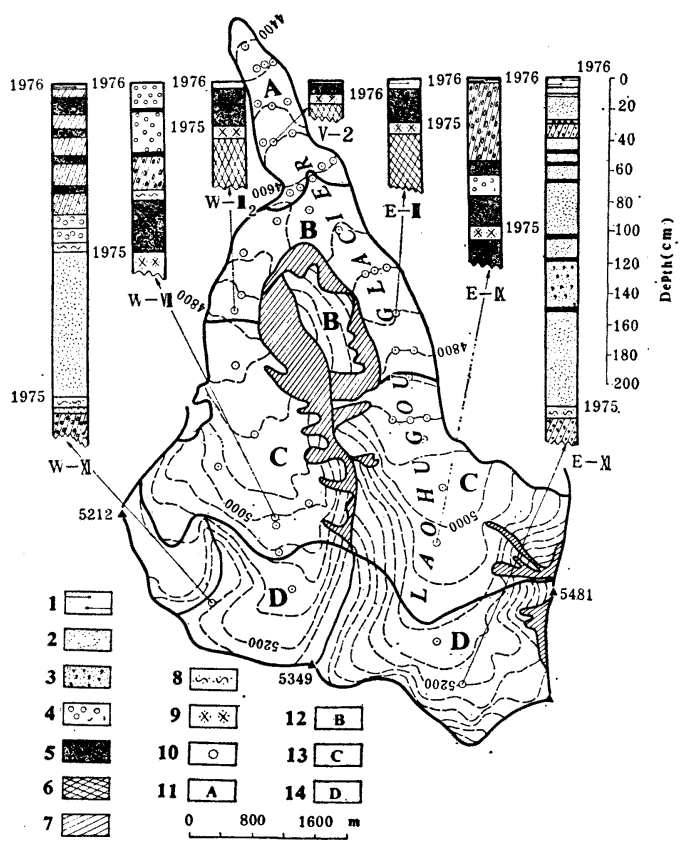

Fig. 3 Sketch map of the distribution of the iceformation zones on Laohugou Glacier, Qilian Shan (August 1976) (from Xie Zichu, unpublished work, 1979)

1. Wind crust; 2. Fine-grained snow; 3. Mediumgrained snow; 4. Coarse-grained snow; 5 . Ice of infiltration and congelation; 6. Ice of dynamo-metamorphism; 7. Densely-packed snow; 8. Slightly dirty level; 9. Heavily dirty level; 10. Point of observation; 11. Zone of seasonal infiltration and congelation; 12. Zone of infiltration and congelation; 13. Zone of infiltration; 14. Zone of cold infiltration and recrystallization.

the glaciers, the velocity of motion of continental type is comparatively slow. The ice velocity of the large glaciers of over $20 \mathrm{~km}$ long may reaches about 100 $\mathrm{ma}^{-1}$. at the upper part of the ice tongue. That in the glaciers about $10 \mathrm{~km}$ long is less than $40 \mathrm{ma}^{-1}$. and in cirque glaciers or cirque valley glaciers shorter than $6 \mathrm{~km}$ is within $20 \mathrm{ma}^{-1}$. The erosion effect of glaciers is weaker. In the empty cirques and the troughs, lakes or rock basins formed by the strong abrasion of glaciers are rarely seen.

The maritime type glaciers in the southeastern part of Xizang are well developed under the condition of rich precipitation in summer. Li Jijun and others have observed an annual precipitation of about $2,500 \mathrm{~mm}$ 


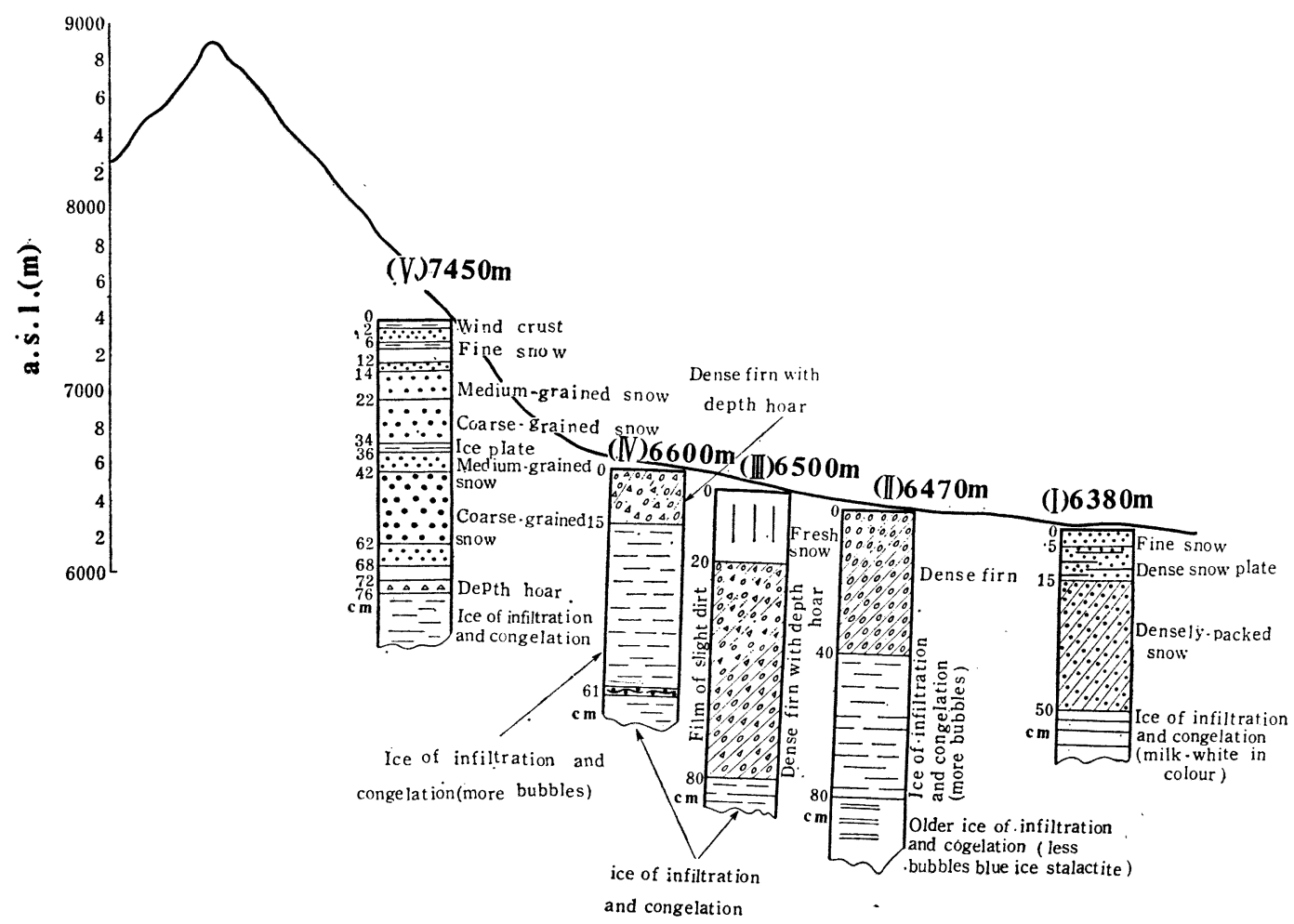

Fig. 4 Cross section showing firn layer at diverse heights above the firn line on East Rongbuk Glacier (from Division of Glaciology, Academia Sinica, 1975)

and an annual mean air temperature of about $-4^{\circ} \mathrm{C}$ near the snow-line of Azha Glacier in the Nyainqentanglha and the annual ablation depth at the terminus of ice tongue reaches or over $10 \mathrm{ma}^{-1}$. The metamorphasis of snow and its subsequent transformation into ice is mainly the action of warm infiltration, and the ice temperature at the bottom of the active layer of the glacier is at pressure melting point $(\mathrm{Li}$, 1975). Wang Zhonglong and others measured the ice temperature in July and August with a depth of $10 \mathrm{~m}$ from the ice tongue of Kougsiang Glacier and found that all near $0^{\circ} \mathrm{C}$. Among ablation heat sources in summer, $26 \%$ is from turbulent exchange and $10 \%$ from condensation (Wang Zhonlong, unpublished work, 1966). The velocity of motion of maritime glaciers is greater. Li (1975) observed a maximum speed at the upper part of the ice tongue of the Azha Glacier reaching $438 \mathrm{ma}^{-1}$. and the middle part reaching $276 \mathrm{ma}^{-1}$, all having quick block sliding. The terminus of larger maritime type glaciers descend to the sub- tropical forest zones, $3,000 \mathrm{~m}$ a.s.l. or even lower. Englacial and subglacial ablation is very strong. All the melt water flows out from the ice cavern. The erosive power of the maritime type glaciers is stronger than that of continental type of the same magnitude, and their cirques are deeply concave, in the troughs are more rock basins, and at places where glacier is disappeared there often occur lakes either in the cirques or in the valleys.

Between the maritime glaciers and the continental ones, there is a transitional zone of various width, especially at Karkoram, Pamir and the highest peak area of Tian Shan and it may also occurs on the southern slope of Himalaya. Several large glaciers, having a great difference in height from the source to the end at $4,000 \mathrm{~m}$ or more, go across several climatic zones including permafrost, temperate and subtropic. The characteristics of such glaciers have changed greatly: and form what is called the complex type of glaciers If we take the Batura Glacier at the northwesterr 


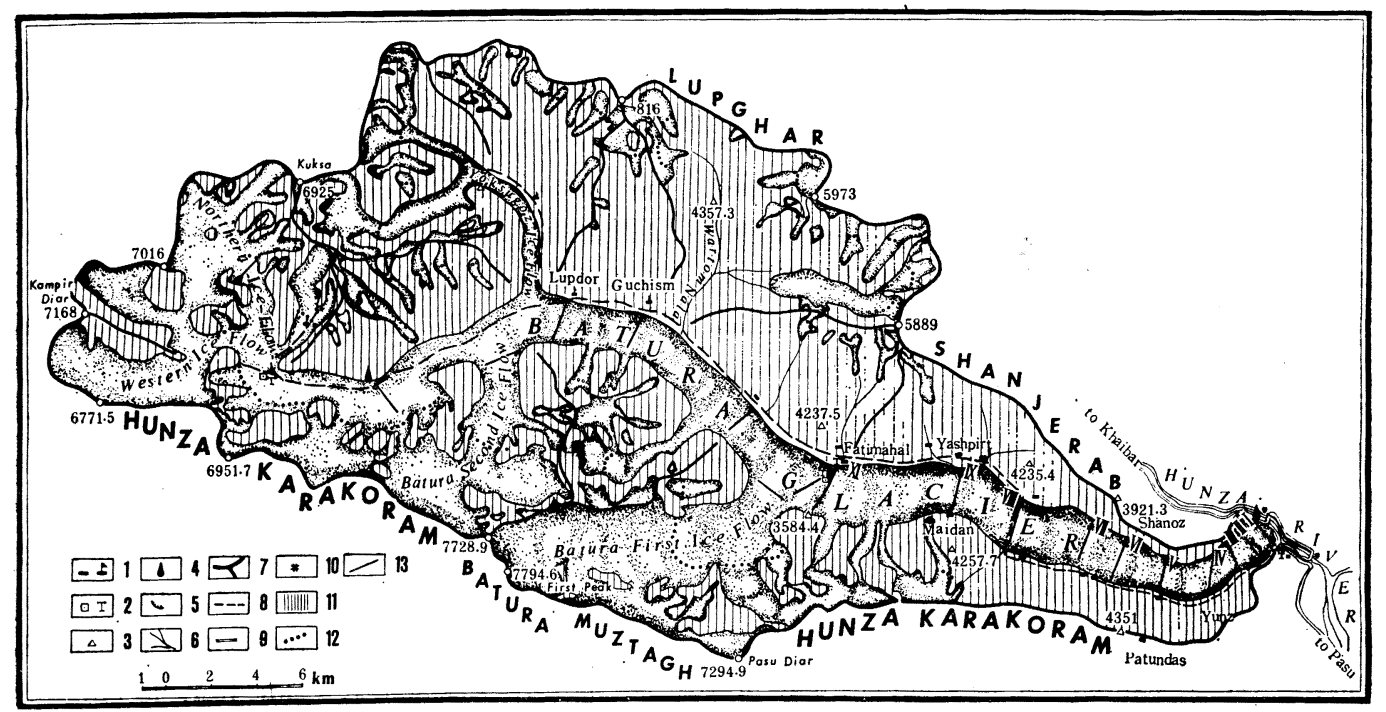

Fig. 5 Schematic map of the Batura Glacier

1. Camp huts; 2. Runoff station, meteorological station; 3. Triangulation point; 4. Drill hole for measuring ice temperature; 5. Ice cavern, ice cliff; 6. River; 7. Divide; 8. Route for expedition; 9. Highway; 10. Hydrological section; 11. Nonglaciated area; 12. Snowline; 13. Cross section for measuring ice motion, ablation and gravity.

part of Karkoram as an example (Batura Glacier Investigation Group, 1974; Fig. 5), it is $59.2 \mathrm{~km}$ long with an area of $285 \mathrm{~km}^{2}$ and is a valley glacier of dendritic form. The highest peak at its source, Batura Muztagh, is $7,995 \mathrm{~m}$ a.s.l. and its terminus descends down to $2,540 \mathrm{~m}$ in Hunza valley with a difference in height reaching $5,455 \mathrm{~m}$. At the firn basin near the snowline, the annual net accumulation reaches $1,000-1,300 \mathrm{~mm}$. From the amount of melt-water of the glacier, it is roughly estimated that the annual precipitation at the accumulation area may reaches about $2,000 \mathrm{~mm}$. The average air temperature near the snowline may be about $-5^{\circ} \mathrm{C}$. The ice formation still belongs to cold metamorphic type. Near the snowline, there distributes a zone of seasonal superimposed ice. The ice temperature in the active layer at $4,500 \mathrm{~m}$ height in summer is below $-1.5^{\circ} \mathrm{C}$, while at $3,300 \mathrm{~m}$ height it raises to $-0.5-0.9^{\circ} \mathrm{C}$, and further reaches $0^{\circ} \mathrm{C}$ at $2,560 \mathrm{~m}$. The maximum thickness of the glacier as measured by gravimeter is $432 \mathrm{~m}$. It reduces to $85 \mathrm{~m}$ near the glacial terminus. The ice motion is rather quick. On the longitudinal profile, there appear alternative changes of high speed and low speed sections, we measured that the highest speed was $517.5 \mathrm{ma}^{-1}$ below an icefall and it reduced to $30 \mathrm{ma}^{-1}$ on the ice cliff at the glacial snout. The arid even desert scenery dominates in Hunza valley and the annual precipitation reaches only about 100 $\mathrm{mm}$. The heat source of glacial ablation is mainly from solar radiation. The maximum depth of annual ablation on the bare ice at 2,600 m a.s.l. was measured as $18.4 \mathrm{ma}^{-1}$, but the larger part of ice surface 20 $\mathrm{km}$ long at the lower portion which covered with thick debris reduced to $4.36 \mathrm{ma}^{-1}$ water layer. The total amount of meltwater on the ice surface all goes down through the crevasses and ice wells forming integral and unified subglacial channels, and torrentially flowing out of the ice caverns at the snout. Within the recent 200 years, the Glacier has advanced twice and receded twice. At present it is in a new advance. But in every case the magnitude of advance and recession is not over $1 \mathrm{~km}$. If it is compared with the length of the Glacier, it is rather small. In a word, the Batura Glacier changes from wet-cold condition in the upper reach to arid-warm in the lower, while on the nature of ice temperature it is from cold glacier in the upper to temperate one in lower. The drywarm climate in the lower reach (annual mean temperature is about $10^{\circ} \mathrm{C}$ ) might lead to a very strong 
ablation, but the thick debris cover protects the glacier, and extends its terminus to lower position by high speed of ice motion. These comlicated features makes the glacier impossible to be generalized under the category of continental or maritime. It is suggested that the eight large glaciers with a length over $50 \mathrm{~km}$ in the mountains of Central Asia (6 in Karakoram, 1 in Pamir, and 1 in Tian Shan) are all of complex type. Other glaciers that cross several climatic zones and have changed considerably the physical characteristics (as from cold glaciers to temperate ones) may be also classified into this complex type.

\section{Variations of Glaciers}

In the fifty's and at the beginning of sixty's, the Chinese glaciologists reported without exception that glaciers in China were on the decline, but only in a few places the observations were repeated, such as the Muzart Glacier in Tian Shan (29 km long) retreated $750 \mathrm{~m}$ in 1909-1959, and 3 glaciers in Muztagata of Pamir retreated with $1.7-3.7 \mathrm{ma}^{-1}$. in 1956-1960. The scope of glacial investigation in the seventy's is enlarged. Comparison of various aerial photos, Landsat images, and maps of different years in the past show that a large part of glaciers are still receding, but mass budget of several glaciers is in positive value, snowline is descending and small part of glaciers are clearly advancing.

The changes in terminus of the 35 small glaciers in Qilian Shan (all within $10 \mathrm{~km}$ long) have been recorded succesively for 20 years. According to the statistics of Xie Zichu (Investigation Team on Utilization of Ice and Snow Resources in the Qilian Shan, 1980), in the years 1956-1976, eight glaciers at the eastern section (Lenglong Ling) receded with a rate of 12.5-22.5 ma-1. Among the 18 glaciers at the middle and northwestern section, 14 receded with a rate of 1.0-7.1 ma-1, 4 were stable at their terminus. The Laohugou No. 12 Glacier is the longest one in Qilian Shan. It is $10 \mathrm{~km}$ long. Field surveying showed that it retreated $71.8 \mathrm{~m}$ during the period from May 1962 to August 1976 at a mean rate of $5.13 \mathrm{ma}^{-1}$. In recent years the rate of recession of glaciers obviously reduced, such as Shuiguan He No. 4 Glacier at Lenglong Ling receded $16 \mathrm{ma}^{-1}$ on the average in 1956-1975, but decreased to $6 \mathrm{ma}^{-1}$ in 976-1978. Among 9 glaciers at southwestern part of Qilian Shan in 1966-1976, 6 were in advancing and 3 in receding. (Mi Desheng, unpublished work, 1980). The Yikixiahalgenol No. 1 glacier is a typical flat topped glacier. Its three ice tongues are all advancing with the values of $992 \mathrm{~m}$, $101 \mathrm{~m}$ and $101 \mathrm{~m}$ respectively. From 1974, 4 glaciers in Qilian Shan where mass budgets were under observation, all appear positive value successively for several years, for instance "July 1st" Glacier had a 3-year (19741977) positive values reaching $768 \mathrm{~mm}$ water-layer in total. The year 1976 was the turning point of temperature change in recent years. The temperature of $1967-1976$ in Qilian Shan decreased at $0.8-1.3^{\circ} \mathrm{C}$ as compared with that of 9 years before 1967. The decrease in temperature in 1967 effected many places in Northern Hemisphere. This year. in Soviet Altai at a place $2,150 \mathrm{~m}$ a.s.l. the temperature of JuneSeptember was $1.2^{\circ} \mathrm{C}$ lower than the ordinary years, precipitation has increased by $162 \mathrm{~mm}$ (Horvath, 1975).

Thirty-nine glaciers in Tian Shan mountains (19 among them exceed $10 \mathrm{~km}$ long) have their record of changes at an interval of 10 to 30 or more years. According to preliminary statistics of Ren Binghui (unpublished work, 1979), 24 of them have clear sign recession, while 5 are eminently advancing. Among the receding glaciers, No. 1 of the Urumqi He $(2.2 \mathrm{~km}$ long) receded at $75 \mathrm{~m}$ in 1962-1973 on an average of $6.9 \mathrm{ma}^{-1}$, Akdas No. 6 Glacier of the Jingou He, Irianhabika mountain, $14 \mathrm{~km}$ long receded at $1.5 \mathrm{~km}$ as seen from 1964 aerial map compared with 1972 Landsat image, giving an average recession of $188 \mathrm{ma}^{-1}$. All the 5 advancing glaciers are over $10 \mathrm{~km}$ long and located in the southern slope of Tumor peak. Two of them (Kochikarbashi and Saichiba) make an advance of $850 \mathrm{~m}$ and $2,100 \mathrm{~m}$ respectively, according to 1942 1976 records, and three glaciers (Arilangsu and two at Ujunduxi $\mathrm{He}$ source) advanced $1,800 \mathrm{~m}, 300 \mathrm{~m}$ and $600 \mathrm{~m}$ respectively, according to 1963-1976 records. Soveit Tienshan data of 13 small glaciers (1.4 to $11.5 \mathrm{~km}$ long) in 1970-1974 showed 7 in recession, 2 in advance and 4 in stable condition (Müller, 1977).

Three glaciers in the Muztagata and Kongur Shan of Pamir made eminent advance in 1956-1978 with their terminus descending $70-300 \mathrm{~m}$ in height. It is roughly estimated that their advancement ranged from 
several hundred meters to $1 \mathrm{~km}$. Among the eight small glaciers (the longest is $6.4 \mathrm{~km}$ ) in Soviet Pamirs as recorded in 1970-1974, 7 glaciers were advancing and only one was retreating (Müller, 1977).

Majority of large glaciers $(7.4 \mathrm{~km}-30.4 \mathrm{~km}$ long) in the western part of Kunlun in Xinjiang were in a state of recession, as investigated by Deng Yungxin (unpublished work, 1979) from the comparison of 1976 Landsat images with 1968 aerial topographic maps, at a scale of $100 \mathrm{~m}$ to $1,000 \mathrm{~m}$ and an average rate of recession 12.5-137.5 $\mathrm{ma}^{-1}$. But the Kunlun Glacier with its terminus at $4,920 \mathrm{~m}$ advanced forward about $370 \mathrm{~m}$ by comparing aerial map of October 1970 with the Landsat image of November 1976. The Chuanshuikou Glacier $10 \mathrm{~km}$ in length advanced at a rate of $15.5 \mathrm{ma}^{-1}$ from 1968-1976. In the Kunlun mountain on the border of Qinghai and Xinjiang, Mi Desheng (unpublished work, 1979) made a comparison of 1976 Landsat images with 1969-1971 aerial maps for 31 glaciers (all of medium and small glaciers). It was found that 14 of them had their position of terminus showing advancement with a range of 90-420 m, 11 showing recession at $100-250 \mathrm{~m}$, while 7 having changes not prominent. Some glaciers in Anyemaqen Shan at the east end of Kunlun are advancing in the past ten or mone years. Deng Yangxin (unpublished work, 1979) found that the Yaherung Glacier advanced 1,8002,000 m from November 1966 to July 1977.
Glaciers in Karakoram mountains at the end of last century and the beginning of this century were in majority advancing, generally retreating in the 30 's to 60 's, and in recent years of 60's and 70's advancing going along side with retreating. Six out of 11 glaciers along the China-Pakistan Highway in the territory of Pakistan were receding, as surveyed by Zhang Xiangsong (1980a) showing a recession of $30-600 \mathrm{~m}$ in 1966-1978, while 5 of them turned into prominent advancement of $132 \mathrm{~m}$ (Batura Glacier), $150 \mathrm{~m}$ (Minaping Glacier) and $320 \mathrm{~m}$ (Khunjirab No. 1 Glacier) respectively in 1966-1978. The other 2 are of surging glaciers. The famous vigorously advancing and retreating glacier, Hasanabad Glacier, after the great recession of 1925-1954, turned into a comparatively rapid advance. The long separated east and west branch met together again. In 1954-1978, the east branch advanced $1.5 \mathrm{~km}$, while the west $4.8 \mathrm{~km}$ (Fig. 6). The newly discovered Baltbar Glacier had an catastrophic debris flow which obstructed the Hunza River in 1974. According to actual measurement, this glacier of about $10 \mathrm{~km}$ long had its position of terminus in 1978 advancing $1.7-2.0 \mathrm{~km}$ as compared with that of 1974. Three out of 5 glaciers $(8.5 \mathrm{~km}-41.5 \mathrm{~km}$ long) flowing into the upper Yarkant $\mathrm{He}$ on the northwest of $\mathrm{Mt}$. Qogir $\left(\mathrm{K}_{2}\right)$, were in recession, comparing the positions of terminus on the Landsat images with that on the 2 maps of 1937 and 1968. Among

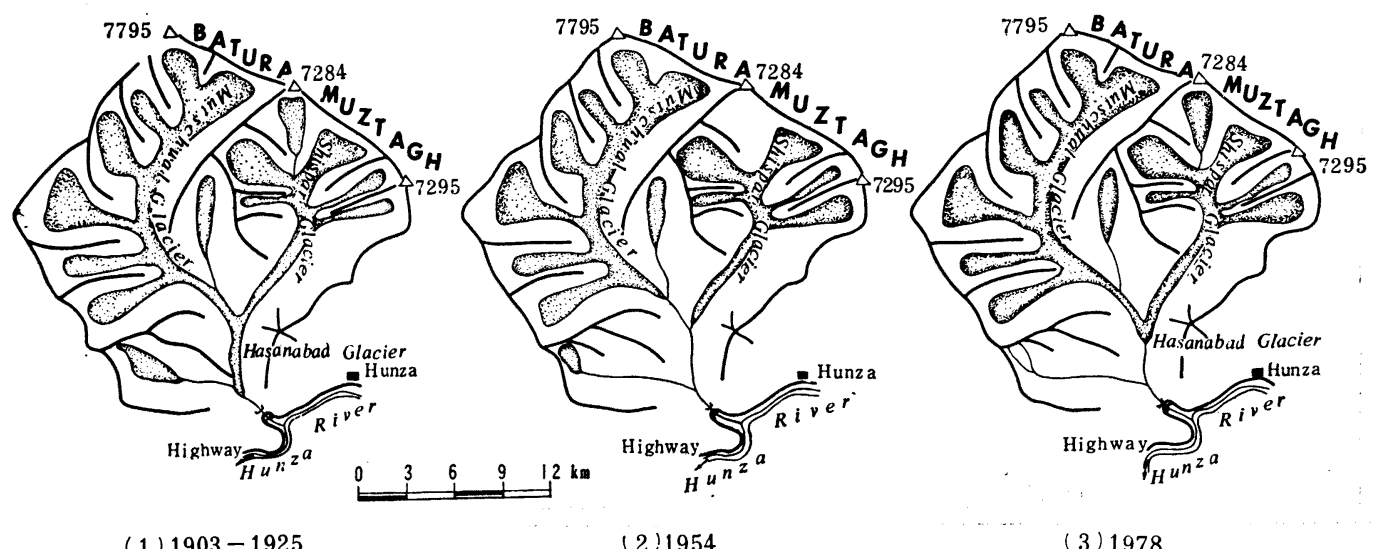

(1) $1903-1925$

(2)1954

(3) 1978

Fig. 6 Variations in the positions of terminus of the Hasanabad Glacier (1903-1978)

(1) 1903-1925 (from Hayden, 1907; Mason, 1930)

(2) 1954 (from Paffin et al., 1956)

(3) 1978 (from Zhang Xiangsong, 1980a) 
them the Skyang Glacier (northeast of $\mathrm{K}_{2}, 18.8 \mathrm{~km}$ long) receded $5.25 \mathrm{~km}$ from 1937 to 1978, it is the glacier having the greatest recession known in China. Two glaciers were advancing. One was the abovementioned Insukati Glacier-the longest in the territory of China. Though its terminus was covered by the thick debris and was stable in 1937-1978, yet the lowest position of the naked ice stretched downward about $5 \mathrm{~km}$. Another was the Braldu Glacier in the territory of Pakistan $35 \mathrm{~km}$ long with thick debris cover at the terminus also. In 1937-1968, the position of terminus was unchanged, yet the lower limit of naked ice streched $4 \mathrm{~km}$ downward, and in 1968-1978 it developed to be having an eminent advance of terminus at a distance of $900 \mathrm{~m}$ (Zhang, 1980b). In Mount Qomolangma area, the lower limit of two nakek ice flow on the west Rongbuk Glacier advanced $306 \mathrm{~m}$ and $553 \mathrm{~m}$ by comparing the map surveyed in 1966 and Landsat image of 1976. Conversely, the white and clean ice of East Rongbuk Glacier retreated about
$210 \mathrm{~m}$ during the same period. In 1969 to 1976 , the lower limit of bare ice of Jiuda Glacier advanced 150 $\mathrm{m}$ and that of Kyabrak Glacier retreated 1,340 m. (Mi Desheng, unpublished work, 1980).

In East Nyaingentanglha, the famous Azha Glacier has retreated $193 \mathrm{~m}$ in 1973 to 1977 . But the fieldwork in 1976 showed that the ice movement had accelerated. Comparison of Landsat images of 1977 and 1978, the Azha Glacier has already advanced about 200 m (Mi Desheng, unpublished work, 1980).

According to incomplete statistical data from various sources, mainly from the comparison of aerial maps of 1960's and Landsat images of 1970's, among 155 glaciers in West China, 40 are advancing, 86 retreating and 29 stable.

The Karakoram Highway linking two countries, China and Pakistan, passes through the terminus of the well-known Batura Glacier. It is necessary to forecast its advancing and retreating changes in a certain future period so that this part of highway

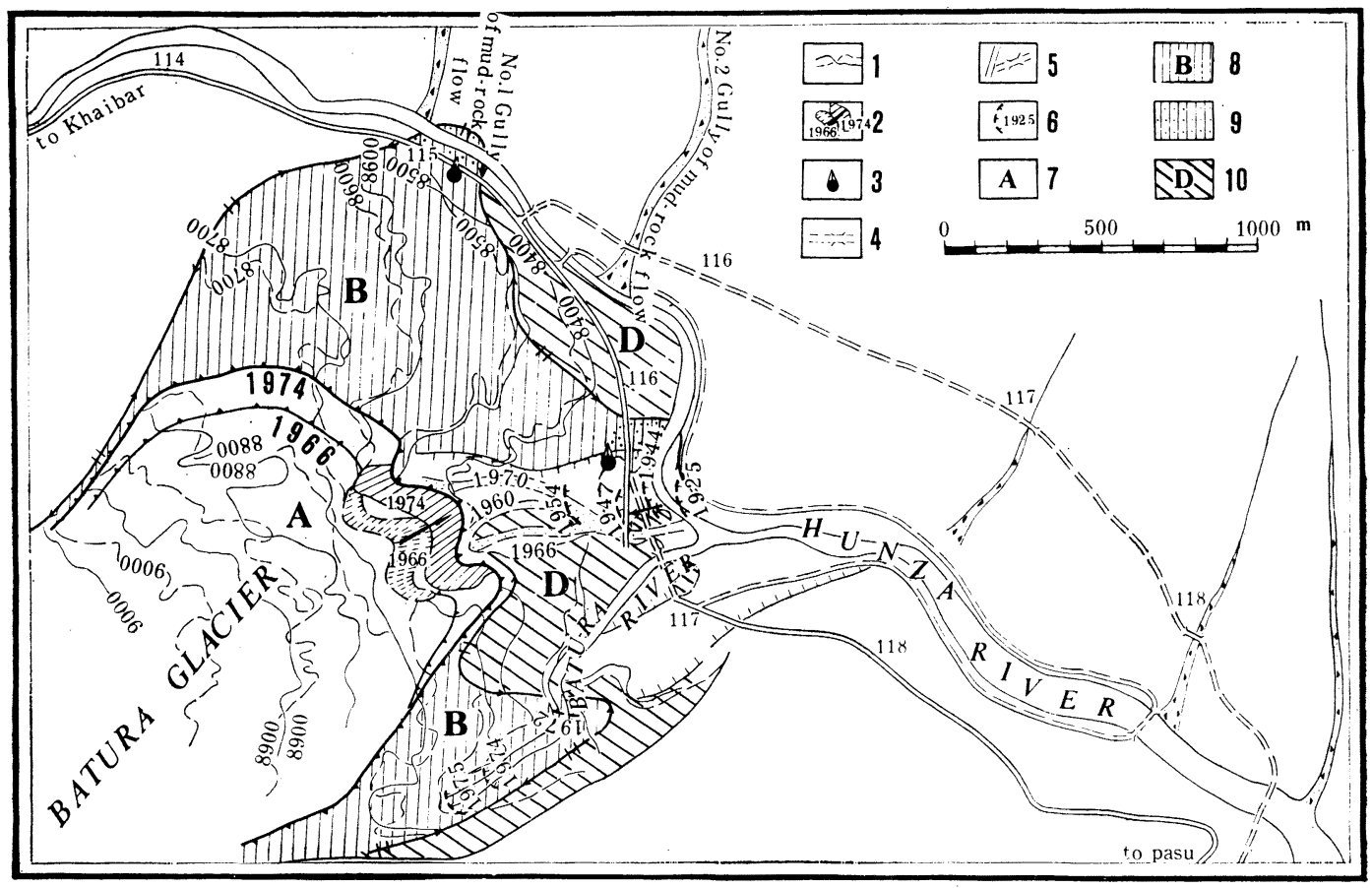

Fig. 7 The terminal changes of the Batura Glacier

1. Displacement of contours (ft) and date; 2. Displacement and date of terminal ice cliff; 3. Bore hole; 4. Highway, temporary roa-lway, bridge; 5.Planned alternate line; 6. Drainage cavern; 7. Markedly advancing and thickening area of the Batura Glacier of present-day; 8. Thick greyish moraine hills with buried ice; 9. Without buried ice; 10. Yellowish moraine hills formed two centuries ago. 


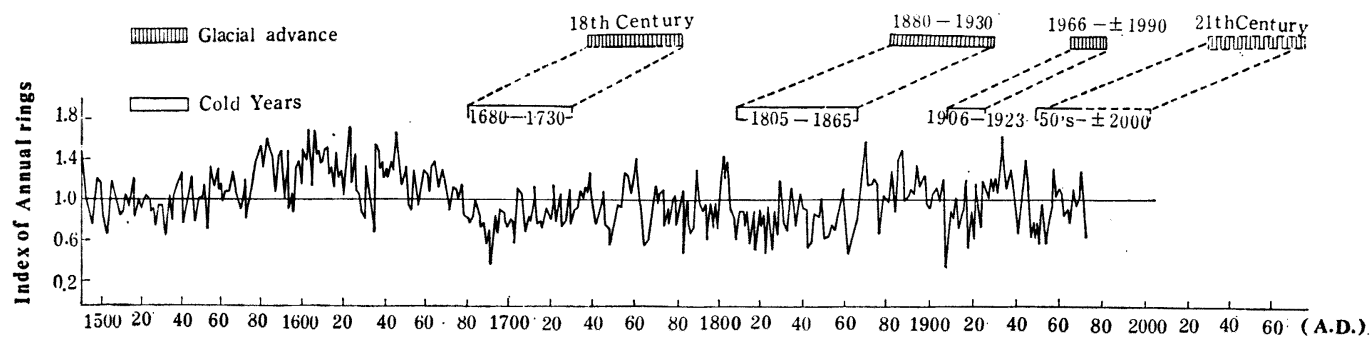

Fig. 8 The time lag of the Batura Glacier advance behind the cold years since 17 th century

engineering project may be decided. For this purpose, we went comparatively deep study of the history of the glacial terminus. We have found that within 200 years, the Batura Glacier has had three advances and two recessions (Fig. 7). The three advances were in the time of 18th century, 1880-1930, and after $1966^{\circ}$ The most pressing problem at present is to make certain the extent of the advance after 1966 and would it effect the safety of the Highway built between the terminus of the Glacier and the bank of Hunza River. We try to forecast in following three ways:

(1) We use the lagging property of the advance of glacier corresponding to the period of wet-cold climate to forecast the changes of glaciers. The growth rate of trees near the upper limit of the forest zone is mainly effected by temperature, and the width of their annual ring sensitively reflects the change in climate. We analized a tree of Sabina grown at $3,800 \mathrm{~m}$ a.s.l. near the glacier, which is 484 years old. Fig. 8 shows the corresponding relationship between the changes in the indices of the annual rings of the Sabina and the advance of the Glacier. In the Karakoram mountains, the decrease in temperature is closely related to the increase of precipitation. In the wet and cold years, accumulation increases, ice layer thickens, ablation weakens, and the energy is transmitted to the terminus of the glacier through the kinematic wave so as to make a new advance. According to the actual measurement made at Nisqually Glacier in the Northwest America (Johnson, 1954; Hodge, 1974), the kinematic wave velocity may be roughly estimated as 2-6 times of that of ice velocity. Calculated from the actual velocity of ice flow in the Batura Glacier the transmission of ice body from the snowline to the terminus on different ice flow needs 180-340 years.
Considering the fact that the velocity of kinematic wave may be several times higher than that of ice flow, it is rational to infer that the advance of Batura Glacier lags several score of years behing the period of wetcold climate. From the variation in indices of annual rings as shown in Fig. 8, we find that there was a high temperature period from the middle of the 16th century to the 70's of the 17 th century and after that was a comparatively long period of low temperature, especially the two prominent periods in 1680-1730 and 1805-1865. After 1865, temperature rose again and the climate became the warmest in 1930's of this century in which a small low temperature interval appeared in 19061923. But from the fifties on, the temperature has been falling again. According to the cyclic change of width in annual ring and the forecast of change in world climate by certain researchers, this low temperature period may last till about 2000 A.D. The above-mentioned three advances of Batura Glacier corresponded to the low temperature periods as below: the advance of glacier in the 18th century corresponding to the low temperature period of $1680-1730$, the advance in 1880 1930 to that of 1805-1865, and the advance after 1966 to the small low temperature interval of 1906-1923. In summary, the advance of the Batura glacier lags behind the climatic wet-cold period by $50-70$ years. The fall of temperature begining from fifties reduces ablation of ice and facilitates the advance of glacier since 1966. If this assumption agrees with the fact, it would be reasonable to predict that scale of glacier advance since 1966 which is caused by the smalı low temperature period of 1906-1923 should be smaller than the previous two advances of the 18th century and the years from 1880 to 1930 , and that the low temperature tendency since the fifties may last till the 
end of this century and lead to a new advance of glacier in the next century (Shi and Zhang, 1978)

(2) Forecast of Glacial Variation by the Decreasing Rate of Ice Flow Velocity at Glacial Terminus. Considering the fact that the Batura Glacier is an active, normal glacier and not a rampant surge one and the ice velocity measured by the German-Austrian Himalaya Karakoram Expedition in 1954 was near to that of Chinese measured in 1974-1975, we can see that the change in motion velocity is not great and the speed of movement of the Batura Glacier over the $1.2 \mathrm{~km}$ distance between the profile III and the great ice cliff at the terminus is gradually decreasing as shown in Fig. 9. The motion velocity at the ice cliff was $30 \mathrm{ma}^{-1}$ in 1974 and 1975 and its real advancing value at its foreground was $10 \mathrm{ma}^{-1}$. The discrepancy between them, that is $20 \mathrm{ma}^{-1}$ is the ablation value of the cliff. We assume that this value is stable, and when the Glacier is advancing and motion velocity is decreasing successively to $20 \mathrm{ma}^{-1}$, the glacier will stop

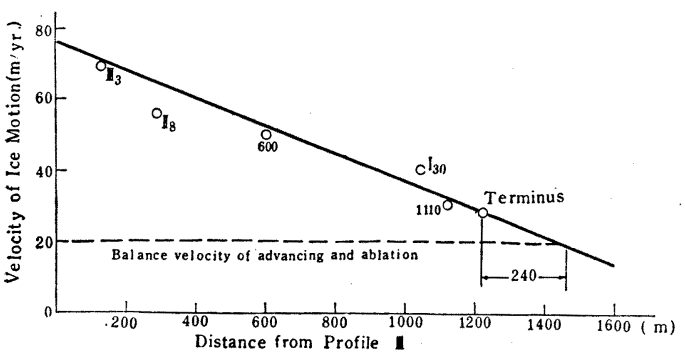

Fig. 9 The decreasing rate of velocity at the terminus of the Batura Glacier its advancing. From the explanation of Fig. 9, we would like to estimate the advancingi amount of ice cliff reaches $240 \mathrm{~m}$. That is since 1976, the glacier successively advances $240 \mathrm{~m}$, reaching the limit value (Batura Glacier Investigation Group, 1979).

(3) Forecast of Glacial Variation by Fluctuation of Ice Discharge Balance.

It is impossible for us to make an overall calculation of ice discharge balance of the Batura glacier. But it is possible to make a comparatively detailed measurement of motion velocity, ablation, and thickness in its lower part about $20 \mathrm{~km}$ in length. For this, we divided the lower part into 9 divisions and find their balance calculations between the ice flux and ablation. The result is shown in the following table (Table 3 ).

From Table 3, we can see that between Profile III and Profile XI there is a discrepancy of input ice, giving a negative value of balance, resulting in a deficit large enough to lower the ice surface by 0.59 $-4.91 \mathrm{ma}^{-1}$. From profile III down to Profile II, there is a comparatively surplus of ice, sufficient to raise the ice surface $2.42 \mathrm{ma}^{-1}$ increasing the speed of ice flow (the ice thickness in Proporition to the ice velocity roughly corresponds with $1 \mathrm{~m}$ to $0.55 \mathrm{ma}^{-1}$ ) permitting the advance of the glacier going on. But the input at Profile III, effect by the lowering of ice surface in its upper stream and the velocity of ice flow, will be rapidly decreased, and when it is transmitted to Profile II and will also make the ice flux at Profile II decrease. Taking into consideration the

Table 3 The balance of ice quantity in the lower reaches of the Batura Glacier (1974-1975)

\begin{tabular}{|c|c|c|c|c|c|c|c|c|c|c|}
\hline Profile & XI & IX & VIII & VII & VI & V & IV & III & II & $\begin{array}{l}\text { Terminal } \\
\text { Ice Cliff }\end{array}$ \\
\hline $\begin{array}{l}\text { Distance from the } \\
\text { highway }(\mathrm{km})\end{array}$ & 20.1 & 15.3 & 12.5 & 9.6 & 8.1 & 5.2 & 3.2 & 1.9 & 1.0 & 0.53 \\
\hline $\begin{array}{l}\text { Area of cross section } \\
\quad\left(10,000 \mathrm{~m}^{2}\right)\end{array}$ & 73.43 & 55.29 & 57.57 & 48.46 & 37.37 & 28.91 & 23.36 & 16.05 & 14.54 & \\
\hline $\begin{array}{l}\text { Mean velocity of cross } \\
\text { section }\left(\mathrm{ma}^{-1}\right)\end{array}$ & 138.1 & 127.6 & 113.4 & 80.7 & 68.0 & 65.2 & 46.1 & 67.9 & 24.2 & \\
\hline Annual ice flux $\left(10,000 \mathrm{~m}^{3}\right)$ & 10,140 & 7,055 & 6,528 & 3,910 & 2,541 & 1,885 & 1,077 & 1,090 & 352 & \\
\hline $\begin{array}{l}\text { Surface area between two } \\
\text { profiles }\left(10,000 \mathrm{~m}^{2}\right)\end{array}$ & $1,272.5$ & 638,25 & 705.2 & 358.3 & 375.2 & 361.8 & 136.8 & 132.0 & 124.6 & \\
\hline $\begin{array}{l}\text { Ablation between two } \\
\text { profiles }\left(10,000 \mathrm{~m}^{3}\right)\end{array}$ & 6,515 & 3,658 & 3,596 & 1,581 & 1,559 & 1,916 & 395 & 419 & 216 & \\
\hline $\begin{array}{l}\text { Balance of ice amount } \\
\quad\left(10,000 \mathrm{~m}^{3}\right)\end{array}$ & $-3,450$ & $-3,131$ & -978 & -212 & -903 & $-1,108$ & -405 & 319 & 136 & \\
\hline $\begin{array}{l}\text { Equivalent to ice surface } \\
\text { or fall }(\mathbf{m})\end{array}$ & -2.7 & -4.91 & -1.39 & -0.59 & -2.41 & -3.06 & -2.96 & 2.42 & 1.90 & \\
\hline
\end{tabular}


speed of kinematic wave propagation on a glacier, we can calculate the ice flux at Profile II that is necessary for the glacier to prceed advancing. Besides, we have also considered the necessary thickness and ablation for its further advancing. Thus, we roughly estimate: from 1966 the maximum magnitude of successive advance of the glacier is $180 \mathrm{~m}$ and its last time stop of advance will be about 1991 (Batura Glacier Investigation Group, 1979).

After 3 years, the Chinese Glacier Investigation Group again in 1978 observed the Batura Glacier and found that the ice cliff at its terminus has advanced continuously $32.3 \mathrm{~m}$, this approaches our forecast. But the increment value of ice flow velocity at Profile II is lower than the foretold amount. This means the advance of the glacier may finish before the time previously estimated and the magnitude of advance is smaller than the above-mentioned $180 \mathrm{~m}$.

\section{References}

Avsyuk, G. A., 1956: Temperatura l'da v lednikakh. Trudy instituta geografii, 67, 63-141.

Batura Glacier Investigation Group, Lanzhou Institute of Glaciology and Cryopedology, Academia Sinica, 1974: The Batura Glacier in the Karakoram Mountains and its variations. Scientia Sinica, 22, 8, 958-974.

Division of Glaciology, Lauzhou Institute of Glaciology, Cryopedology and Desert Research, Academia Sinica, 1975: Basic features of the glaciers of the Mount Qomolangma Region, Southern part of the Tibet Autonomous Region, China. Scientia Sinica, 18, 1, 106-130.

Hayden, H., 1907: Notes on certain glaciera in the Northwest Kashmir. Records of the Geological Survey of India, 35, 127-137.

Hodge, S. M., 1974: Variations in the Sliding of a temperate glacier. J. Glaciol., 13, 69, 349-369.

Horvath, E., 1975: Glaciers of Altaysko-Sayanskaya Strana. Mountain Glaciers of the Northern Hemisphere. CRREL, 1, 297-309.

Investigation Team on Utilization of Ice and Snow Resources in the Qilian Shan, Lanzhou Institute of Glaciology and Cryopedology, Acade- mia Sinica, 1980: A preliminary study on recent fluctuation of glaciers in the Qilian Shan. Acta Geographica Sinica, 35, 1, 57-66.

Johnson, A., 1954: Observations on Nisqually Glacier and other glaciers in the Northwestern United States. Assemblée Générale de Rome. IAHS. Publ. 39, 511-516.

Li Jijun, 1975: New data on glaciers in Southeastern Xizang, J. Lanzhou University (natural sciences), 2, 115-123 (in Chinese).

Mason, K., 1930: The glaciers of the Karakoram and neighbourhood. Records of the Geological Survey of India, 63, 214-278.

Müller, F., 1977: Fluctuations of Glaciers 1970-1975. IAHS (ICSI)-UNESCO.

Paffin, K. H., Pillewizer, W. and Schneider, H. J., 1956: Forschungen im Hunza-Karakorum, Vorläufiger Bericht über die Wissenschaftlichen arbeiten der Deutsch-Österreichischen Himalaya-Karakorum Expedition 1954. Erdkunde, 10, 1, 1-33.

Shi Yafeng and Xie Zichu, 1964: The basic characteristics of existing glaciers in China. Acta Geographica Sinica, 30, 3, 183-213 (in Chinese).

Shi Yafeng, Wang Fuban and Wang Zhongtai, 1975: Ice pyramids and other landform on the glacial ablation area in Mount Qomolongma. Report on the Mount Qomolangma Area Scientific Expedition 1966-1968. Glaciology and Geomorphology, 77-91 (in Chinese).

Shi Yafeng and Zhang Xiangsong, 1978: Historical variations in the advance and retreat of the Batura Glacier in the Karakoram Mountains. Acta Geographica Sinica, 33, 1, 27-41.

Shi Yafen, Xie Zichu, Zheng Benxing and Li Jichun, 1980: Distribution, features and variations of glaciers in China. World Glacier Inventory (Proceedings of the Riederalp Workshop, 1978). IAHS Publ., 126, 111-116.

Shumskiy, P. A., 1955: Osnovy Strukturnogo Ledovedeniya. Izd. Akad. Nauk., Moskva, 492 pp.

Zhang Xiangsong, 1980a: Recent variations in the glacial termini along the Karakorum Highway. Acta Geographica Sinica, 35, 2, 159-171.

Zhang Xiangsong, 1980b: Recent variations of the Insukati Glacier and adjacent glaciers in the Karakoram Mountains. J. Glaciology and Cryopedology, 2, 3, 12-16 (in Chinese). 


\section{Abstract \\ Some achievement on mountain glacier researches in China}

Shi Yafeng

(Lanzhou Institute of Glaciology and Cryopedology, Academia Sinica)

Since 1958, Glaciological researches were carried on in Qilian Shan, Tian Shan, Himalaya, Southeast Sizang and other mountains in west China and also Karakoram in Pakistan. The total glacierized area in west China is roughly estimated at about $56,471 \mathrm{~km}^{2}$, nearly a half of that in Central Asia. The snowline ranges between 3,000 $\mathrm{m}$ (Altay) and 6,200 $\mathrm{m}$ (south west Xizang). According to climatic conditions and physical properties (ice formation, ice temperature, heat and mass balance, ice movement, etc.), glaciers in Central Asia could be classified into three types: Continental type (Tian Shan, Qilian Shan, Kunlun Shan, northern slope of Himalaya and interior mountains of Qinghai-Xizang plateau), maritime type (southeast Xizang), and complex type (several longest valley glaciers in Karakoram, Pamir, Tian Shan, southern slope of Himalaya). From the 1950 s to 1960 s, glaciers were retreating, but in 1970 s positive mass balance appeared in some glaciers, and snowline descended. The incomplete data from various sources, mailny by comparing aerial maps of 1960s with Landsat images of 1970s, show that a large part of glaciers are still receding, but the rate of reccession is obviously reduced and a small part of glaciers are clearly advancing.

(Received 11 October 1979; Revised 1 September 1980; Accepted 7 October 1980) 